\title{
Epigraphic Documents from Mersa Gawasis: \\ a Reassessment
}

\author{
Dr.Rosanna Pirelli \\ Director of Italian Cultural Institute \\ For Archeology
}

I shall present in this paper some considerations on the different typologies of stelae until now discovered on the site of Wadi/Mersa Gawasis and on their spatial and chronological distribution. ${ }^{1}$ The analyse of these data could provide, in my opinion, interesting information both on the history of the site, and more widely on the evolution of the use of private stelae during the Middle Kingdom.

\section{The stelae}

Since the beginning of the new investigation by the Italian-American mission, about 25 stelae were discovered, ${ }^{2}$ a number of which was never inscribed; while several of them have been seriously damaged; but at least ten can be almost completely or partially red and can provide us with useful data. ${ }^{3}$ However, in order to have a complete vision of the materials here concerned, the following list contains the whole group of stelae and slabs found by the Italian-American mission in these last years (till season 2006/2007):
1. Stela 1, (niche 1) WG 32
incomplete
(Type II)
2. Stela 2, (niche 2) WG 32
Amenemhat IV (?) (Type II)
3. Stela 3, (niche 8) WG 32 not carved
4. Stela 4, (niche 9) WG 32 not carved
5. Stela 5, (niche 10) WG 32 Amenemhat III (Type I)
6. Stela 6, (niche 12) WG 32 Amenemhat III (Type I)
7. Stela 7 WG 32 not readable 


\begin{tabular}{|c|c|c|c|}
\hline 8. Stela 8 & WG 32 & Amenemhat III & (Type I) \\
\hline 9. Stela 9 & WG 33 & \multicolumn{2}{|c|}{ large granite stela, just rough-shaped } \\
\hline $\begin{array}{l}\text { 10. Stela } 10 \\
\text { cavetto cornice }\end{array}$ & WG 33 & \multicolumn{2}{|c|}{$\begin{array}{r}\text { Sesostris III (?), rectangular with } \\
\text { (Type I) }\end{array}$} \\
\hline 1. Stela 11 & WG 16 & \multicolumn{2}{|l|}{ completely erased } \\
\hline 12. Stela 12 & WG 16 & \multicolumn{2}{|c|}{ anchor reused as a stela (?) } \\
\hline 13. Stela 13 & WG 32 & \multicolumn{2}{|l|}{ completely broken } \\
\hline $\begin{array}{l}\text { 14. Stela } 14 \\
\text { cavetto cornice }\end{array}$ & WG 33 & Sesostris III & $\begin{array}{r}\text { rectangular with } \\
\text { (Type I) }\end{array}$ \\
\hline 15. Stela 2001 & \multicolumn{2}{|c|}{ on the terrace } & (Type I) \\
\hline 16. Stela 2002 & \multicolumn{2}{|c|}{ on the terrace } & (Type I) \\
\hline 17. Stela 16 & WG 33 & Amenemhat III & (Type I) \\
\hline 18. Stela 18 & WG 33 & without inscr. & \\
\hline 19. Stela 19 & WG 33 & erased & \\
\hline 20. Stela 22 & WG 33 & broken & \\
\hline 21. Stela 23 & WG 33 & Amenemhat III & (Type I) \\
\hline 22. Stela 24 & WG 33 & erased & \\
\hline 23. Stela 26 & WG 33 & only a few signs & \\
\hline 24. Stela 28 & WG 33 & Htp di nswt & \\
\hline
\end{tabular}

(Type III)

As to their texts and scenes, we can observe that a great number of them, apart from their dimensions and/or shape, show an almost regular layout, arranged on two registers:

\section{TYPE I}

a) the upper register houses a divine figure (mostly the god Min), in front of the cartouches or the figure of a sovereign;

b) the lower register shows the image of one or more (usually) standing officials, in a gesture of worship and reverence, who report(s) the achievement of an enterprise on behalf of their sovereign.

This layout fits well either with all the round-topped stelae (those found on the terrace in 2001/2002; and those from WG 32 and WG 33 ${ }^{4}$ ), and with 


\section{Rosanna Pirelli}

the two rectangular stelae with cavetto cornice probably dating to the reign of Sesostris III (fig. 1). The same content is expressed also in the two roundtopped stelae from Wadi Gasus. ${ }^{5}$

Till season 2006/7, only two monuments were to be excluded from this category:

\section{TYPE II}

1) Stela 1 (incomplete, upper part missing) ${ }^{6}$ : The almost square slab, is carved only with one human figure, sitting on a chair with bull legs: The room left should be probably completed with the usual offering formula and a table covered with goods.

2) Stela $2^{7}$ : Although very poorly preserved, this stela is complete; it contains, above a scene showing two men on both sides of an offering pile, an "Appeal to the living", followed by the Htp-di-nswt formula ending with the expression $n \quad k A \quad n$ and the names of the two men and their parents. Its extremely bad conditions made it long and laborious its study and highly hypothetical the identification of names and titles. However, on the base of different factors, I dated the stela to the end of the $12^{\text {th }}$, a chronology that is perfectly suitable with the expedition of Amenemhat IV, documented by the inscription of a cargo box found in 2007.

While this typology, (that can define here as Type II of MG) is one of the commonest among Middle Kingdom private stelae, documented above all in the Abydos chapels, ${ }^{8}$ it was completely new at Mersa Gawasis.

\section{TYPE III}

During season 2007/8 more stelae were brought to light, whose study is being led by Sayed el Mahfouz and whose preliminary information will be published soon in the on-line report of the mission; I will only remember here that one of them, dated by a cartouche of Amenemhat III, contains a Htp-di-nswt formula (without any represented scene).

90 


\section{The cult places}

Two typologies of cult places housed the above described stelae on the site:

A) The small circular shrines (henceforth Type A), identified and excavated by Sayed along the coral terrace and partly reinvestigated by the Italian-American mission, ${ }^{9}$ which will have been dealt more in detail by Andrea Manzo in this same conference. They are small tumuli, with an entrance oriented towards the sea, whose walls could be built with cut and reused anchors; in some cases, the resulting slabs could be inscribed with hieroglyphic texts, which report different activities connected with trade expeditions, towards Punt or Bia-Punt, on behalf of the owner and of his sovereign. ${ }^{10}$

More than a proper shrine or cultic place, Type B is an open area, where groups of stelae were housed in niches cut in the rock wall, on the two sides of the entrances to semi-natural caves used as shelters, in trenches WG 32, 16 and 33. ${ }^{11}$

The nature of these areas is more difficult to define, but the presence of several stelae (with their texts addressed to gods) clearly suggested to me that, although mainly devoted to storage and administrative activities ${ }^{12}$, they should also retain a cultic function, even in case restricted to simple offering rituals to local gods, in front of a small altar and/or a niche built against/or carved in the wall. ${ }^{13}$

But till the season 2006/7, no archaeological evidence had emerged to support this hypothesis. Only in the last days of the mission, this conjecture got a stronger validity: from the excavation of the oriental sector of the trench, between the entrances to cave 5 and 6 , two small stone walls came to light; ${ }^{14}$ a few metres on the east, in the same days, a certain amount of pottery dishes were dug: they were stacked inside a larger vase and covered by a line cloth. Dishes of the same typology were also found during the new excavations of the small shrines on the coral terrace. ${ }^{15}$

It is too early to say more on the nature of this small stone structure and of the connected items, but now we can probably suggest that the hypothesis of a niche leaning against the rock wall for performing offering rituals is

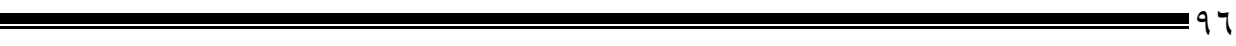




\section{Rosanna Pirelli}

more plausible, although we must wait for the results of the next seasons to confirm it.

At the moment, I find it interesting to point out an extremely revealing chronological datum. Sayed's excavations had focussed, in a first phase, on the coral terrace which, in its northern part, overlooks the sea, before turning towards west and following the line of the wadi. Along the edges of the terrace, the series of small shrines contained texts which belong to the first half of the $12^{\text {th }}$ dynasty. Later investigations were conducted by Sayed also inside the wadi, but here the Egyptian mission discovered some ostraka pertaining to the reign of Sesostris III. ${ }^{16}$

As to the findings of the Italian-American mission, all the inscriptions with a royal cartouche - with or without a specific date - come from trenches opened inside the wadi and are to be put between the reigns of Sesostris III and of Amenemhat IV. ${ }^{17}$

On this base, we can probably infer that at least two different phases can be reconstructed in the life of the port:

a) in a first phase (until the first half of the $12^{\text {th }}$ dynasty), the areas used for cultic purposes were allocated along the terrace, while the inner part of the wadi was reserved to the productive and management activities, ${ }^{18}$ this chronology is also confirmed by the pottery found during the new excavations of two of the shrines: beside the small dishes and a beer jar whose presence is not indicative of a specific and limited period, the typology of a conical bread mould recovered inside one of the inner room of feature 8 , close to the foundation deposit, shows to be older than the usual type found on the site in the productive area and limited to the first half of the $12^{\text {th }}$ dynasty. ${ }^{19}$

b) in the second half of the $12^{\text {th }}$ dynasty, the ceremonial spaces moved towards south-west, inside the wadi, closer to the other functional areas. Here, as we have already said, the epigraphic documents are all dated or datable to the reigns of Sesostris III, Amenemhat III and Amenemhat IV.

Moreover, while the earlier epigraphs were allocated in individual shrines where, at least on the base of our evidence, only one high ranking 9V 
official was represented beyond the king, the later stelae were inserted in common open spaces and usually contained more than one individual, with or without the king: in this phase also familiar ties make their appearance in the inscriptions.

This datum is even more interesting if we compare it with those coming from the inscriptions of other mining sites: ${ }^{20}$

1) A survey of the private epigraphs of Serabit el Khadim revealed that, while the texts of the first half of the 12th dynasty, reported above all the results of the achieved activities, with the name of the responsible and the number of the participants, some new elements make their appearance during the reign of Amenemhat III: the Htp-di-nswt formula, images of the chiefs of the expeditions sitting in front of an offering table, and the "Appeal to the living". 21

2) A similar situation is recorded also among the inscriptions of Wadi elHudi. The texts usually show the same type of content of the previous ones, but I found 5 inscriptions with a Htp di nswt formula: one from the time of Amenemhat III, two from the time of Sobekhotep IV and two more where the name of the king is not preserved.

3) The same is true for the Wadi Hammamat: almost all its Middle Kingdom inscriptions are composed of "Regnal year with the name of the sovereign, a more or less articulated report of the enterprise, name and title of the responsible". But inscription $n^{\circ} 48$ dating to the $19^{\text {th }}$ year of Amenemhat III, for instance, presents a htp di nswt formula, ending with the expression " $n$ kA n", followed by the name of the mr mSa ○nbbw, and his maternal and paternal filiation.

On the base of the above reported data, I think this feature could be usefully employed as a chronological terminus in this kind of sites (that is sites connected to economic and trade activities, rather than to funerary and religious celebrations) : in other words, if it is true that stelae of type I were realized till the end of the Middle Kingdom, I think we can state that the use of stelae of type II and III did not appear in this type of site before the second half of the 12th dynasty, and in particular during the reign of 
Amenemhat III.

This phenomenon moreover seems to correspond - although inserted in a different context - with the "growing spiritualization", that Pflüger (1947) identified in the composition of the funerary stelae of the late $12^{\text {th }}$ dynasty. Although I don't think that today we can completely share his interpretation, the features and the changes, he had singled out in his paper in 1947, seem to coincide with those expressed in our type II and III:

a) development towards simplicity;

b) prevailing of the religious element over the secular one;

c) marked interest in the hereafter.

To these features I would also add:

d) the mention of family ties (in stela $n^{\circ} 1$, for instance)

Thus, between the reigns of Sesostris III and Amenemhat III, two significant changes occur, which only at first sight can be considered conflicting: on the one side

I) we assist to a change from "monumental" and visible structures, erected individually on the coral terrace, to more generic but in the same time intimate places, almost protected in the recesses of the wadi, which seem to indicate a decrease in the prestige of the chiefs of the expeditions, and in the same moment

II) the changes in the texts and representations on the stelae seem to point out a remarkable trend towards a stronger incidence of personal piety and private concern for one's own survival in the memory of the posterity and in the afterlife.

These factors can be better interpreted in my opinion as manifestations of the same reality: the new administrative and bureaucratic order, attributed to the politics of Sesostris III and of his son Amenemhat III, certainly resulted in a higher degree of efficiency of the state, ${ }^{22}$ but in the same time it caused a levelling down of the intermediate ranking officials ${ }^{23}$ and a consequent loosening of their ties with the figure of the king.

Stelae of type II and III are no more monuments which record economic enterprises, devoted to a deity on behalf of the reigning king, but more 99 
personal monuments, whose prior aim is granting, through a prier directed to the gods and through the participation of the living, eternal memory of the represented individuals, and I would go even further in stating that they clearly manifest the research of an individual relationship with god, only partially mediated by the king's presence.

The image of Nebsu just behind (or beside?) Amenemhat III on stela ${ }^{\circ}$ 5 could be considered a turning point in this change; while the absence in type II and III of a reference to profane events may be considered different manifestations of this same feeling. 
Notas

${ }^{1}$ This article was previously presented at the First Neapolitan Congress of Egyptology, held in Naples in June 2008 and organized by ANSE (Associazione Italiana di Studi Egittologici) and is in press in its Proceedings.

${ }^{2}$ Only two of them (n. 2 and n. 5) have already been extensively published: Pirelli in Bard, Fattovich, 2007, p.217-221; Pirelli, 2007;

${ }^{3}$ For a synthesis on their nature and content, see Bard, Fattovich, 2007, p.217-221

${ }^{4}$ On these excavation areas, see next paragraph.

${ }^{5}$ Sayed, 1977, Nibbi, 1976. Even the texts of the slabs from the chapels of Ankhu and Antefoker show the same kind of content, although their conservation doesn't allow to reconstruct their figurative programme. Not all the scholars however accept to put the stela of Khnumhotep among the monuments originally erected in Mersa Gawasis, because its text, dating back to the reign of Sesostris II, doesn't mention Punt but Tanetjer (Nibbi 1976; Bradbury...).

${ }^{6}$ Pirelli, in Bard, Fattovich, p. 217

${ }^{7}$ Pirelli in Bard, Fattovich, 2007, p.217-219; Pirelli, 2007.

${ }^{8}$ ANOC.

${ }^{9}$ Bard, Fattovich, pp. 39-44

${ }^{10}$ Sayed, 1977.

${ }^{11}$ We will concentrate in particular on trench WG 32, whose excavation is more advanced, but in these last years two more areas (see the on line reports on www.Archaeogate.org) were discovered with similar characteristics. Beside them a different structure must be mentioned, a platform made of coral rock and conglomerate slabs, erected on the terrace and oriented towards the sea, whose access was given throough a wide ramp on its west side. The structure (WG 29), dug by R. Fattovich, did not contain stelae, but was associated to a remarkable number (650 ca) of great shells of Lambis lambis (per la cui massiccia presenza sono state avanzate ipotesi di carattere sia funzionale che cultuale, Bard et al., 2006/7, pp. 11-12) e da otto conchiglie di Tridacna (Fattovich, in Bard, Fattovich 2007, p. 43-44).

${ }^{12}$ As R. Fattovich, A. Manzo and C. Zazzaro have reported in this same conference.

${ }^{13}$ As usually attested almost everywhere in Egypt, (either in the Valley or in border areas such as the Eastern desert, near the caves and the mines), the presence of stelae, above all those characterised by the offering formula and the appeal to the living, suggests the existence at least of a niche or a small shrine to present the offerings to the deity, see for instance the shrines of Abydos (ANOC), at Serabit el-Khadim (Valbelle, Bonnet, 1996) and the shrine of Hekaib on Elephantine island (Habachi, 1988 e Franke 1994).

${ }^{14}$ Bard et al., 2006/7.

${ }^{15}$ Personal communication by A. Manzo. They could be used both for presenting offerings in front of the chapels and the niches and for the daily staff rations.

${ }^{16}$ Sayed, 1983; for a chronological review of these data, see Mahfouz, 2006.

${ }^{17}$ Mahfouz in Bard, Fattovich, 2007, pp. 238; Bard et al., 2006/7, pp. 47-48

${ }^{18}$ As is suggested either by the first phase of WG 32 (see Manzo and Pirelli...), or the productives areas identified at the base of the wadi, (Perlingieri, Childs, 2006).

${ }^{19}$ I owe this information to A. Manzo

1.1 
E Epigraphic Documents from Mersa Gawasis: a Reassessment

${ }^{20}$ See below.

21 V. per esempio le iscrizioni $n^{\circ} 93$ e 103 risalenti al regno di Amenemhat III, e le iscrizioni $\mathrm{n}^{\circ} 118$ e 121 del regno di Amenemhat IV (Gardiner/Peet, 1952, p. 100, 107$108,122,124-5)$.

${ }^{22}$ A salso the great number of expeditions dating back to the reign of Amenemhat III, in particular.

23 Seyfried $(19 \ldots)$, p. already noted this difference as to the chiefs of the expeditions during the second half of the XII dynasty. 


\section{Bibliography:}

1. ANOC $=$ SIMPSON W. K., The terrace of the Great God at Abydos: the Offering Chapels of Dynasties 12 \& 13, Philadelphia, 1974.

2. Bard et al. $2006 / 2007=$ BARD K. et al., Joint Archaeological Expedition at Mersa/Wadi Gawasis (Red Sea, Egypt) of the University of Naples "L'Orientale" (Naples, Italy) Istituto Italiano per l'Africa e l'Oriente (Rome, Italy), and Boston University (Boston, USA) - 20062007 Field Season, http://www.archaeogate.org

3. Bard, Fattovich, $2007=$ BARD K. - R. FATTOVICH (eds.), Harbor of the Pharaohs to the Land of Punt. Archaeological Investigations at Mersa/Wadi Gawasis, Egypt, 2001-2005, Napoli 2007

4. Bradbury, 1988 = BRADBURY L., "Reflections on Traveling to 'God's Land' and Punt in the middle Kingdom", JARCE 25, 1988, pp. 140-156

5. Castel, Soukiassian, $1985=$ CASTEL G., G. SOUKIASSIAN "Dépôt de stèles dans le santuaire du Nouvel Empire au Gebel Zeit", BIFAO 85,1985 , p. $285-293$.

6. Franke, 1994 = FRANKE D., Das Heilgtum des Heqaib auf Elephantine, (SAGA 9) 1994.

7. Gardiner/Peet, $1952=$ GARDINER A. and T. E. PEET, The Inscriptions of Sinai I, (EES 45), Ed. by J. Cerny from manuscripts of A.Gardiner and E. Peet, 1952

8. Habachi, 1988 = HABACHI L., The sanctuary of Heqaib at Elephantine, 1988

9. Mahfouz, $2006=$ el-MAHFOUZ S., "Les Ostraca hiératiques du Ouadi Gaouasis » Egypte, Afrique \& Orient 41, 2006, pp. 31-34

10. Manzo, Pirelli, 2006 = MANZO A., R. PIRELLI, "The sealings from Marsa Gawasis ( $\circ \mathrm{Aww}$ ): preliminary considerations on the administration of the port" in Mélanges Abdelmonem Sayed, 2006, pp. 40-96.

11. Nibbi, $1976=$ NIBBI A., "Some remarks on the two stelae from the Wadi Gasus", JEA 62, 1976, pp. 45-56.

12. Perlingieri, Childs, $2006=$ PERLINGIERI C., S.T. CHILDS, "The Production area at Mersa/Wadi Gawasis: Evidence for multiple craft activities", in The Festschrift Volume. A collection of studies presented to Professor Abdel Monem Abdel Haleem Sayed, Alexandria 2006, pp. 101-138. 
E Epigraphic Documents from Mersa Gawasis: a Reassessment

13. Pflüger, $1947=$ PFLÜGER K. "The private funerary stelae of the Middle Kingdom and their importance for the study of Ancient Near Eastern History", JAOS 67, 1947, pp. 127-135.

14. Pirelli 2007 = PIRELLI R., "Two New Stelae from Mersa Gawasis", Revue d'Egyptologie 58, 2007, pp.

15. Sayed, $1977=$ SAYED A. M.,"Discovery of the site of the $12^{\text {th }}$ Dynasty Port at Wadi Gawasis on the Red Sea Shore", RdE 29, 1977, pp. 138-177

16. Valbelle, Bonnet, 1996 = VALBELLE D., C. BONNET, Le sanctuaire d'Hathor maîtresse de la turquoise, Paris, 1996. 